\title{
PENGARUH MODEL PEMBELAJARAN CREATIVE PROBLEM SOLVING (CPS) TERHADAP KEMAMPUAN PEMECAHAN MASALAH DAN HASIL BELAJAR FISIKA
}

\section{THE EFFECT OF CREATIVE PROBLEM SOLVING (CPS) LEARNING MODEL FOR PROBLEM SOLVING ABILITY AND PHYSICS LEARNING ACHIEVEMENT STUDENT}

\author{
Anggun Yunita Wisela ${ }^{1^{*}, \text { Hairunisyah Sahidu², Syahrial Ayub }}{ }^{2}$ \\ ${ }^{1}$ mahasiswa Program Studi Pendidikan Fisika FKIP, Universitas Mataram, Mataram, Indonesia \\ ${ }^{2}$ Program Studi Pendidikan Fisika FKIP, Universitas Mataram, Mataram, Indonesia \\ *Email : anggunyunita25@gmail.com
}

Diterima: 22 November 2019. Disetujui: 3 Desember 2019. Dipublikasikan: 9 Januari 2019

\begin{abstract}
Abstrak: Penelitian ini bertujuan untuk mengetahui pengaruh model pembelajaran creative problem solving terhadap kemampuan pemecahan masalah dan hasil belajar peserta didik SMAN 8 Mataram tahun pelajaran 2019/2020. Jenis penelitian yang digunakan adalah quasi experiment dengan desain penelitian non-equivalent control group design. Populasinya seluruh peserta didik kelas XI MIA SMAN 8 Mataram. Pengambilan sampel penelitian menggunakan teknik purposive sampling, sehingga terpilih peserta didik kelas XI MIA 2 sebagai kelas eksperimen dan kelas XI MIA 1 sebagai kelas kontrol. Kelas eksperimen diberi perlakuan berupa model pembelajaran creative problem solving dan kelas kontrol diberi perlakuan berupa pembelajaran konvensional. Instrumen yang digunakan untuk mengukur kemampuan pemecahan masalah menggunakan instrumen tes uraian sebanyak 4 butir soal untuk mengukur hasil belajar menggunakan instrumen tes pilihan ganda sebanyak 20 butir soal. Hipotesis penelitian diuji menggunakan uji MANOVA berbantuan IBM SPSS 23 dengan taraf signifikansi 5\%. Uji hipotesis MANOVA menghasilkan taraf signifikansi lebih kecil dari 0,05 sehingga $\mathrm{H}_{0}$ ditolak dan $\mathrm{H}_{\mathrm{a}}$ diterima. Berdasarkan hasil analisis tersebut dapat disimpulkan terdapat pengaruh model pembelajaran creative problem solving terhadap hasil belajar dan kemampuan pemecahan masalah fisika peserta didik.
\end{abstract}

Kata Kunci: creative problem solving, kemampuan pemecahan masalah, hasil belajar.

\begin{abstract}
This research aim to find out the effect of creative problem solving (CPS) for problem solving ability and physic learning achievement student participants in SMAN 8 Mataram academic year 2019/2020. This type of research is quasi experiment with non-equivalent control group design. The research population was all students of XI MIA SMAN 8 Mataram. Sampling research using purposive sampling technique, so selected XI MIA 2 class was chosen as the experimental class and the XI MIA 1 class as the control class. Experimental class was given treatment in the form of creative problem solving learning model and control class was given treatment in the form of conventional learning model. The instrument using for quantify of problem solving ability is done by the form of a description test as many as 4 questions and for quantify of physic learning achievement using instrument multiple choices test as many as 20 questions. Hypothesis testing using MANOVA test with IBM SPSS 23 with $5 \%$ of significance level assisted. Hypothesis MANOVA test yielded significance level smaller than 0.05, so as Ho is rejected and Ha to be accepted. Based on the result of this analysis can be concluded that there are effect of creative problem solving learning model for problem solving ability and physics learning achievement student participants.
\end{abstract}

Keyword: creative problem solving, problem solving ability, learning achievement.

\section{PENDAHULUAN}

Pembelajaran adalah proses interaksi peserta didik dengan pendidik dan sumber belajar pada suatu lingkungan belajar [1]. Apabila proses kegiatan pembelajar yang dimaksudkan diselenggarakan secara formal di sekolah, maka diharapkan dapat mengarahkan perubahan pada diri peserta didik secara terencana, baik dalam aspek pengetahuan (kognitif), sikap (afektif) ataupun keterampilan (psikomotor) sehingga pembelajaran merupakan suatu proses yang sangat penting dalam pendidikan [2]. Pembelajaran fisika adalah pembelajaran yang tidak mengabaikan hakikat fisika sebagai sains [3]. Sains pada hakikatnya adalah kumpulan pengetahuan berupa fakta, konsep, teori, dan generaliasasi tentang alam, serta merupakan disiplin ilmu yang ketat, objektif, dan suatu proses yang berbasis kegiatan pengamatan, inferensi, hipotesis dan pecobaan dalam alam [4]. Pembelajaran fisika sebagai sains diharapkan, peserta didik mampu untuk memproses pengetahuan dengan fenomena-fenomena yang ada dikehidupan sekitar akan tetapi, pada kenyataannya, dalam proses pembelajaran fisika masih sangat teoritis dan kurang menerapkan model pembelajaran yang sudah banyak dikembangkan oleh para ahli sampai saat ini sehingga proses pembelajaran fisika cenderung sepihak hal ini tentu mengakibatkan peserta didik kurang dapat mengembangkan kemampuan 
berpikir dalam memproses pengetahuannya dengan fenomena-fenomena yang ada dikehidupan sekitar.

Hasil observasi peneliti menunjukkan pembelajaran fisika di SMA Negeri 8 Mataram masih menggunakan pendekatan yang didominasi oleh peran guru (teacher centered). Pembelajaran yang bersifat teacher centered merupakan pembelajaran yang lebih banyak menempatkan peserta didik sebagai objek bukan sebagai subjek [5]. Pada sistem ini, selama proses pembelajaran peserta didik kurang diberikan kesempatan untuk mengembangkan kemampuan berpikir yang mengakibatkan peserta didik cenderung pasif dan hanya terpaku pada persamaan yang diberikan oleh guru. Hasil nilai rata-rata ujian tengah semester 1 peserta didik untuk mata pelajaran fisika tahun pelajaran 2018/2019 masih tergolong rendah hal ini diduga diakibatkan karena kurangnya kemampuan peserta didik dalam mengembangkan, ataupun mengaplikasikan teori yang diperoleh. Keberhasilan belajar sendiri merupakan tahap pencapaian yang dapat dilihat dari perilaku peserta didik yang meliputi aspek kognitif, afektif maupun psikomotor, menurut Bloom terdapat 6 tingkatan penilaian hasil belajar aspek kognitif diantaranya, knowledge (pengetahuan), comprehension (pemahaman), application (aplikasi), analyse (analisis), synthesis (sintesis), dan evaluation (evaluasi) [6].

Berdasarkan permasalahan yang dihadapi selama proses pembelajaran fisika tersebut maka diperlukan model pembelajaran berbasis pada pemecahan masalah (problem solving) yang mampu melibatkan peserta didik secara aktif untuk mengembangkan kemampuan berpikir kreatif sehingga pembelajaran menjadi lebih bermakna. Peningkatan kemampuan peserta didik dalam mengembangkan kreativitas berpikir diharapkan dapat meningkatkan kemampuan pemecahan masalah sehingga hasil belajar fisika juga meningkat. Pemecahan masalah pada pembelajaran fisika pada hakikatnya adalah belajar berpikir atau bernalar untuk mengaplikasikan pengetahuanpengetahuan yang telah diperoleh untuk memecahkan masalah yang baru. Adapun menurut Gagne yang dikutip oleh Wena pemecahan masalah tidak hanya menuntut seseorang untuk menerapkan pengetahuannya dalam menyelesaikan masalah tersebut, tetapi juga melatihnya untuk menemukan pengetahuan baru [7]. Langkah-langkah kemampuan pemecahan masalah fisika menurut Young and Freedman (2012) menggunakan I SEE yaitu, identify (mengindentifikasi masalah), set up (merencanakan strategi), execute (menerapkan strategi), evaluate (evaluasi) [8].

Model pembelajaran yang dapat menjadi solusi menurut peneliti adalah model pemeblajaran creative problem solving (CPS). Model pembelajaran CPS merupakan suatu model pembelajaran yang melakukan pemusatan pada pengajaran dan keterampilan pemecahan masalah dan berpikir kreatif yang diikuti penguatan keterampilan dengan fase CPS terdiri dari, objective finding, fact finding, problem finding, idea finding, solution finding, acceptance finding [9]. Dengan membiasakan peserta didik menggunakan langkah-langkah kreatif dalam memecahkan masalah diharapkan ketika peserta didik dihadapkan dengan suatu pertanyaan, peserta didik dapat melakukan keterampilan memecahkan masalah untuk memilih dan mengembangkan solusi dari permasalahan yang dihadapi dan kesulitan dalam proses pembelajaran fisika, dengan tidak hanya menghafal penjelasan yang diberikan oleh guru tanpa berpikir sehingga dapat meningkatkan kemampuan pemecahan masalah dan hasil belajar.

Sejalan dengan penelitian terdahulu yang dilakukan oleh Fitriyah, Nimatul dkk (2015) menyatakan bahwa adanya pengaruh model pembelajaran CPS dengan Mind Mapping terhadap kemampuan berpikir kreatif dan hasil belajar IPA Biologi peserta didik kelas VII SMP Negeri 11 Jember tahun pelajaran 2014/2015 [10] dan Penelitian lainnya yang dilakukan oleh Hariawan dkk (2013) menyimpulkan bahwa terdapat pengaruh model pembelajaran CPS terhadap kemampuan siswa dalam memecahkan masalah fisika [11].

Berdasarkan pertimbangan tersebut model pembelajaran CPS dirasa tepat untuk digunakan di SMA Negeri 8 Mataram yang didukung dari hasil studi pendahuluan yang dilakukan melalui observasi. Peneliti berharap dengan diterapkannya model pembelajaran CPS dapat mengembangkan kemampuan berpikir kreatif sehingga meningkatkan kemampuan peserta didik dalam memecahkan masalah dan hasil belajar pada pembelajaran fisika khususnya di SMA Negeri 8 Mataram.

\section{METODE PENELITIAN}

Jenis penelitian ini adalah quasi eksperiment dengan populasi seluruh peserta didik kelas XI MIA SMA Negeri 8 Mataram. Desain penelitian yaitu nonequivalent control group design dimana penelitian ini melibatkan dua kelas sebegai sampel yang dipilih melalui teknik purposive sampling sehingga terpilih kelas XI MIA 2 sebagai kelas eksperimen yang diberikan perlakuan berupa model pembelajaran CPS dan kelas XI MIA 1 sebagai kelas kontrol yang diberikan perlakuan berupa model pembelajaran konvensional. Data yang diambil dari penelitian ini berupa kemampuan peserta didik dalam memecahkan masalah dengan memberikan tes soal uraian, hasil belajar fisika pada ranah kognitif dengan memerikan tes soal pilihan ganda diawal dan akhir pada materi elastisitas dan hukum hooke yang diperoleh melalui pretest dan posttest pada tiap kelas. Untuk lebih 
jelasnya desain penelitian dapat dilihat pada tabel $1[12]$.

Tabel 1. Desain Penelitian

\begin{tabular}{lccc}
\hline \multicolumn{1}{c}{ Kelas } & Pretest & Perlakuan & Posttest \\
\hline Eksperimen & $\mathrm{O}$ & $\mathrm{X}$ & $\mathrm{O}$ \\
Kontrol & $\mathrm{O}$ & & $\mathrm{O}$ \\
\hline
\end{tabular}

Keterangan:

$\mathrm{X}$ : Model pembelajaran CPS

$\mathrm{O}$ : pretest dan posttet

\section{HASIL DAN PEMBAHASAN}

Selama pemberian perlakuan dengan menggunakan model pembelajaran CPS untuk kelas eksperimen dan model konvensional untuk kelas kontrol, peserta didik diberikan pretest dan posttest untuk pokok pembahasan materi elastisitas dan hukum Hooke. Data yang diperoleh meliputi kemampuan pemecahan masalah yang terdiri dari 4 soal uraian dan 20 soal pilihan ganda untuk hasil belajar ranah kognitif serta untuk ranah afektif dan psikomotor dilakukan penilaian melalui observasi selama proses pembelajaran.

Adapun nilai rata-rata peserta didik untuk pretest dan posttest hasil belajar dapat dilihat pada Gambar 1 .

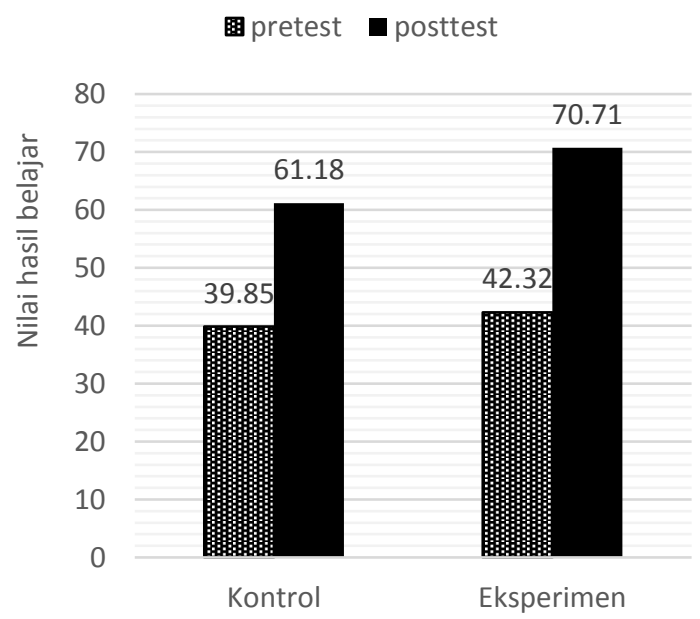

Gambar 1. Grafik Perbandingan Nilai Rata-Rata Hasil Belajar Berdasarkan Pretest dan Posttest Kelas Eksperimen Dan Kontrol

Berdasarkan Gambar 1. terlihat bahwa kedua kelas mengalami peningkatan nilai hasil belajar. Peningkatan tertinggi terjadi di kelas eksperimen. Kelas kontrol yang menggunakan pembelajaran konvensional menjadikan guru sebagai pusat informasi atau fasilitator yang mengakibatkan peserta didik menjadi tidak aktif untuk bertanya dan menyampaikan pendapat di kelas sehingga peserta didik cenderung untuk hanya menerima dan menghafal dari penjelasan guru. selain nilai ratarata pretest dan posttest hasil belajar diukur juga pretest dan posttest kemampuan pemecahan masalah berikut disajikan pada Gambar 2 .

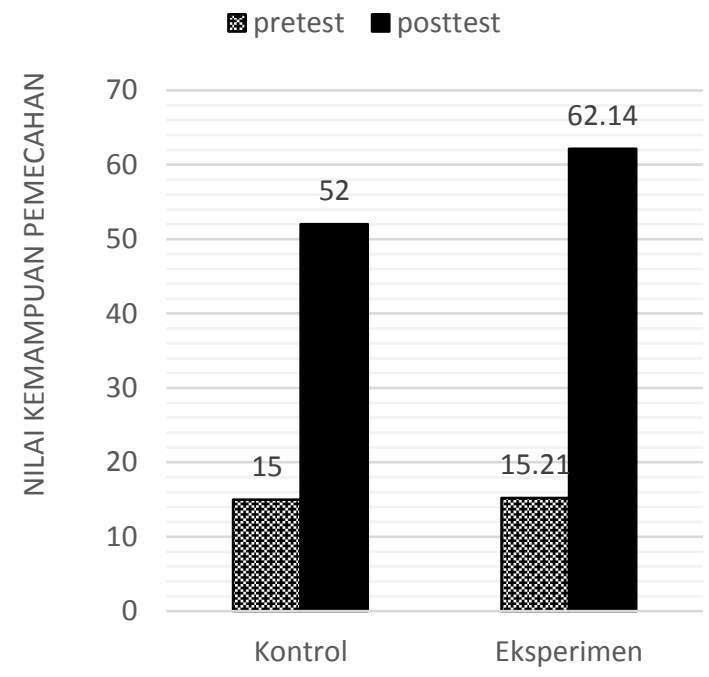

Gambar 2. Grafik Perbandingan Nilai Rata-Rata Kemampuan Pemecahan Masalah Berdasarkan Pretest dan Posttest Kelas Eksperimen Dan Kontrol

Perbandingan dari data hasil rata-rata hasil belajar dan kemampuan pemecahan masalah terlihat bahwa peningkatan tertinggi terjadi di kelas eksperimen. Diperolehnya hasil tersebut kemungkinan karena dalam pembelajaran menggunakan model creative problem solving, peserta didik berperan aktif dalam setiap proses pembelajaran dan secara kreatif berusaha menemukan solusi dari pertanyaan atau permasalahan yang diberikan, saling berinteraksi antara teman ataupun guru, saling bertukar pikiran, dan melakukan percobaan yang berkaitan langsung dengan materi, sehingga wawasan dan daya pikir mereka menjadi berkembang. Salah satu contoh pada pokok pembahasan elastisitas dimana peneliti bertanya dan mendemonstrasikan kegiatan: "karet dan plastisin merupakan benda yang sering kalian temui dalam kehidupan sehari-hari, jika kedua benda tersebut kita berikan gaya tarik maka benda tersebut akan berubah bentuk, benda manakah yang dapat kembali ke bentuk semula setelah gaya yang diberikan dihilangkan?". Secara antusias peserta didik menjawab pertanyaan yang diberikan sesuai dengan hasil demontrasi yang dilakukan peneliti dan peserta didik. Selanjutnya, peneliti meneruskan pertanyaan: "dari kedua benda tersebut benda manakah yang bersifat elastis dan benda yang bersifat plastis?", disini terjadi perdebatan antara peserta didik sehingga membangkitkan rasa ingin tahu mereka dengan jawaban yang sebenarnya. Akan tetapi, peneliti tidak langsung memberikan jawaban benar atau salah melainkan melanjutkan dengan menyampaikan tujuan pembelajaran dan memberikan materi elastisitas untuk menanamkan pemahaman peserta didik untuk menyelesaikan masalah yang dihadapi. Tahap selanjutnya peneliti 
membagi peserta didik menjadi beberapa kelompok heterogen yang terdiri dari 5 sampai 6 anak dimana peserta didik dituntut untuk berdiskusi kelompok guna bertukar pikiran dalam melakukan kegiatan percobaan serta menjawab permasalahan yang diberikan oleh guru pada LKPD. Pada kegiatan ini terlihat peserta didik mencoba menjawab pertanyaan tersebut secara berkelompok dan mencoba menggunakan literature yang ada dan menghubungkannya dengan percobaan yang telah dilakukan guna mendukung dalam menyelesaikan permasalahan yang dihadapi. Pada tahap ini peserta didik menjadi mampu mengembangkan ide, wawasan, dan aktif dalam proses pembelajaran. Selanjutnya setelah peserta didik selesai mengerjakan LKPD guru meminta perwakilan dari salah satu kelompok untuk mempersentasikan hasil diskusi dan percobaannya ke depan dan kelompok lainnya menanggapi hasil diskusi temannya, setelah guru menampung hasil diskusi dan pendapat dari beberapa peserta didik. Selanjutnya guru bersamasama dengan peserta didik menyimpulkan hasil percobaan dan hasil diskusi, setelah peserta didik dirasa memahami materi kemudian guru menanyakan kembali mengenai pertanyaan awal dan peserta didik langsung menjawab pertanyaan ini sesuai dengan konsep dan hasil diskusi yang telah didapatkan. Kegiatan ini membuktikan bahwa model pembelajaran CPS bukan hanya berpengaruh pada hasil belajar ranah kognitif yang dilihat dari nilai post-test yang lebih tinggi dibandingkan dengan kelas kontrol akan tetapi dilihat juga melalui hasil belajar ranah afektif dan psikomotor peserta didik selama proses kegiatan pembelajaran seperti kemampuan peserta didik dalam merangkai serta menggunakan alat dan bahan percobaan, mengolah data, sikap peserta didik pada saat bekerjasama dalam diskusi, cara peserta didik dalam menyampaikan pendapat, dan rasa tanggung jawab dari peserta didik terhadap tugas yang diberikan oleh guru.

Pembuktian adanya pengaruh perlakuan terhadap hasil belajar dan kemampuan pemecahan masalah maka dilakukan uji hipotesis. Uji hipotesis yang digunakan adalah uji MANOVA yang menunjukkan bahwa terdapat pengaruh model CPS terhadap kemampuan pemecahan masalah dan hasil belajar fisika peserta didik. Pengaruh ini berupa peningkatan kemampuan pemecahan masalah dan hasil belajar secara simultan. Hasil tersebut sejalan dengan penelitian yang dilakukan oleh yang dilakukan oleh Fitriyah, Nimatul dkk (2015) menyatakan bahwa adanya pengaruh model pembelajaran CPS dengan Mind Mapping terhadap kemampuan berpikir kreatif dan hasil belajar IPA Biologi peserta didik kelas VII SMP Negeri 11 Jember tahun pelajaran 2014/2015 dan Penelitian lainnya yang dilakukan oleh Hariawan dkk (2013) menyimpulkan bahwa terdapat pengaruh model pembelajaran CPS terhadap kemampuan siswa dalam memecahkan masalah fisika.

Penelitian ini tak luput dari keterbatasan, baik yang berasal dari sistem (model, peserta didik, keadaan lapangan) maupun dari peneliti itu sendiri. Adapun berbagai keterbatasan tersebut yaitu peneliti kesulitan untuk mengimplementasikan model pembelajaran creative problem solving seperti halnya kekurangan pada problem solving pada penelitian sebelumnya, memang peneliti membutuhkan alokasi waktu yang cukup lama selain karena model ini jarang digunakan pada pembelajaran fisika peserta didik juga merasa asing dengan cara peneliti membangun pengetahuan mereka. Model CPS pada dasarnya dapat merangsang peserta didik untuk berpikir kreatif dalam memecahkan masalah karena pada saat proses pembelajaran peserta didik akan diberikan topik diskusi berupa LKPD, teridiri dari soal-soal dan langkah percobaan yang dapat merangsang ide dan gagasan peserta didik untuk memecahkan soalsoal tersebut dengan mencari fakta berdasarkan hasil dari percobaan yang dilakukan serta membaca buku dan berdiskusi. Namun pada saat penerapannya, peneliti memiliki keterbatasan yaitu pada saat percobaan berlangsung beberapa peserta didik kurang antusias melakukan percobaan dikarenakan percobaan dalam pembelajaran fisika merupakan sesuatu hal yang sangat jarang didapatkan oleh peserta didik di SMAN 8 Mataram dan pada saat kegiatan diskusi berlangsung peserta didik cenderung mendiskusikan hal-hal diluar dari materi pelajaran yang sedang dibahas bila peserta didik tidak diawasi oleh peneliti. Kendala lainnya, yang dirasa peneliti tidak semua pokok pembahasan pada materi fisika juga cocok dengan model ini karena tidak semua materi dapat dihubungkan dengan permasalahan yang berkaitan pada kehidupan sehari-hari. Terlepas dari segala kekurangan dalam penelitian ini, peneliti telah membuktikan bahwa model pembelajaran CPS berpengaruh terhadap kemampuan pemecahan masalah dan hasil belajar peserta didik kelas XI di SMA Negeri 8 Mataram.

\section{KESIMPULAN}

Berdasarkan hasil penelitian dan pembahasan dapat disimpulkan bahwa terdapat pengaruh model pembelajaran CPS terhadap kemampuan pemecahan masalah dan hasil belajar fisika peserta didik di SMA Negeri 8 Mataram tahun pelajaran 2019/2020. Model pembelajaran CPS dapat dijadikan alternatif model pembelajaran yang dapat meningkatkan kemampuan pemecahan masalah dan hasil belajar fisika peserta didik dengan memperhatikan materi dan subjek penelitian yang lebih luas. Selain itu, selama proses kegiatan pembelajaran berlangsung khususnya pada fase fact finding dan idea finding diperlukan perencanaan dan persiapan yang matang sehingga 
waktu yang digunakan selama proses pembelajaran dapat efisien untuk mencapai tujuan yang hendak dicapai.

\section{DAFTAR PUSTAKA}

[1] Hikmawati. 2014. Strategi Pembelajaran Fisika. Mataram: FKIP Press.

[2] Supardi. 2015. Penilaian Autentik Pembelajaran Afektif, Kognitif dan Psikomotor (Konsep dan Aplikasi). Jakarta: PT Raja Grafindo Persada.

[3] Gunawan. 2015. Model Pembelajaran Sains Berbasis ICT. Mataram: FKIP Universitas Mataram.

[4] Sumaji, S. 2009. Pendidikan Sains yang Humanistis. Yogyakarta: Kasinus.

[5] Rokhmat, J., Marzuki, Hikmawati, \& Verawati, N. N. 2017. The Causal Model in Physics Learning with a Causaliticthinking Approach to Increase the Problem-solving Ability of Pre-service Teachers. SOCIAL SCIENCES \& HUMANITIES, 25(1), 153.

[6] Sahidu, H. 2016. Evaluasi Pembelajaran Fisika. Mataram: FKIP Unram.

[7] Wena, M. 2013. Strategi pembelajaran inovatif kontemporer suatu tinjauan konseptual operasional. Jakarta: Bumi Aksara.

[8] Sujarwanto, E., Hidayat, A., \& Wartono, W. 2014. Kemampuan pemecahan masalah fisika pada modeling instruction pada siswa SMA kelas XI. Jurnal Pendidikan IPA Indonesia, 3(1).

[9] Rosmala, A. 2018. Model-model Pembelajaran Matematika. Jakarta: PT Bumi Aksara.

[10] Fitriyah, N., Hariani, S. A., \& Fikri, K. 2015. Pengaruh Model Pembelajaran Creative Problem Solving dengan Mind Mapping terhadap Kemampuan Berpikir Kreatif dan Hasil Belajar IPA Biologi. Jurnal Edukasi, 2(2), 44-50.

[11] Hariawan, H., Kamaluddin, \& Wahyono. 2013. Pengaruh Model Pembelajaran Creative Problem Solving Terhadap Kemampuan Memecahkan Masalah Fisika pada Siswa Kelas XI SMA Negeri 4 Palu. Jurnal Pendidikan Fisika Tadulako 1(2), 4854.

[12] Sugiyono. 2017. Metode Penelitian Pendidikan: Pendekatan Kuantitatif, Kualitatif, Dan R\&D. Bandung: Alfabeta. 